\title{
Problems in Rehabilitation of Sequelae of Cerebrovascular Accidents
}

by

Kan SHIBATA, Masaaki UGAKI· Junichiro MORIYA

Junichi KURIYAMA and Atsuo WATARI

Department of Medicine, Okayama Rhosai Hospital

\section{ABSTRACT}

ne hundred patients given rehabilitation programs during a period of about
7 years for the sequelae of cerebrovascular accicents at the Okayama Rhosai Hospital were reviewed for an evaluation of therapy. Physiotherapy employed consisted of an active exercise, particluarly ambulation exercise training. All the cases obtained recovery of the function of the lower extremities to the point of single crutch walking after an average period of 2.7 months, but recovery of the function of the upper extremities were not so good.

Most of the technical problems have been solved, but there are still unsolved defficulties in the approach to upper extremity training, mental and speech disturbances and paraplegic ataxia.

Mortality rate does not seem to be increased during and after rehabilitation programs. From various viewpoints a conclusion has been reachedon the advisability of providing rehabilitation programs for the sequelae of cerebrovascular accidents.

Cardiovascular specialists are to be responsible for these situations with an assistance of physical therapists. However, under the present Japaense circumstances where there is yet no speciality system, internists should take care of these problems. It is quite natural that this can be effectively carried out with collaboration of orthopedic surgeons and neurologists.

\section{脳卒中後遺症のリハビリテーションの問題点

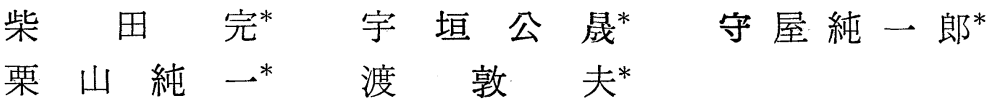

はじめに

日本の国民死因の首位を占めているの脳卒中

* 岡山学災病院内科
である。幸いにして死を免れた者は半身不随を主 とする後遺症に悩まされ，その多くがかつての労 働能力を失い，のみならず他人の手を煩わしてい る者も決して少なくない。その数は意外に多く， 
脳卒中死亡率の比較的低い岡山県1)においても， 患者は約 9,000 人と推定されており2)，このうち 約 3,000人が介助を要するものと推定される ${ }^{3)}$ 。 これらの患者になんらかの形で医学的リハビリテ ーションのみを施すにしても, 到底いかんともし がたい現況にある。リハビリテーションの価值が 認識されるならば，相応の施策が立てられねばな るまい。脳卒中後遺症のリハビリテーションの普 及を困難にしている要因は多々あろうが，回復訓 練の効果に対する疑惑，効果があったにしても， 再発の多い患者にとってどれほどの価值があるか の疑問, 担当科の問題, 運営上の採算などが主た るもののように思われる。

さきに半身不随の治療（リハビリテー ション) について私どもの成績の概略を 報告し4)，歩行可能までには必ず回復す るものであることを強調した。その後症 例もかなり増加し，ますます自信を強め るに至った。そこでその後の成績を再検 討し，実際上の問題点を種々の角度から 考案してみたいと思う。

\section{I. 自 験 例}

昭和31年から昭和38年10月まで（調査 対象がちょうど 100 人になる）の脳卒中後遺症を もった退院患者は総数 125 人であった。そのう ち, 卒中状態で入院し，引き続き死亡した 3 人， 麻㾇が軽く回復訓練を要しなかった 9 人, 中途退 院した人を除くと調查対象は 100 人となる。中途 退院の 13 人の中に両側不随 7 人が含まれたこと は, 両側不随が運動失調を伴いやすく，ために歩 行訓練の対象になり難い点で注目すべきことであ る。調查対象 100 人についての年齢は平均 53.5 歳 で，20〜78歳にわたる。78歳の高齢者も必ずしも 不適格ではない。

性別は男69人，女 31 人で男子が多かった。 麻瘴側は右側 52 人, 左側 47 人でほぼ同数, 両側 も1 人見られた。

発病すなわち卒中発作から入院までの期間は， とくに長い65，96月の 2 人を除けば，平均 4.2 月 で，0から23月にわたっている。

全入院期間は平均 4.5 月で，1から20月におよ
んでいる。入院期間は発病から入院までの期間に 大きく左右され，関節の拘縮・変形をきたしてい る例では入院期間はいちじるしく延長した。また 目標に一応到達しても患者が退院したがらない傾 向が見受けられた。退院の基準は歩行不能者では 自立歩行可能, その他の者では 3 月以内とした。

基礎疾患は94人が高血圧でほとんどを占め, 弁 膜症 3 人, 紫斑病・くも膜下出血各 1 人で等った。

\section{II.リハビリテーションの概要}

その詳細はさきに報告したので4) 省略する（図 1 参照)。

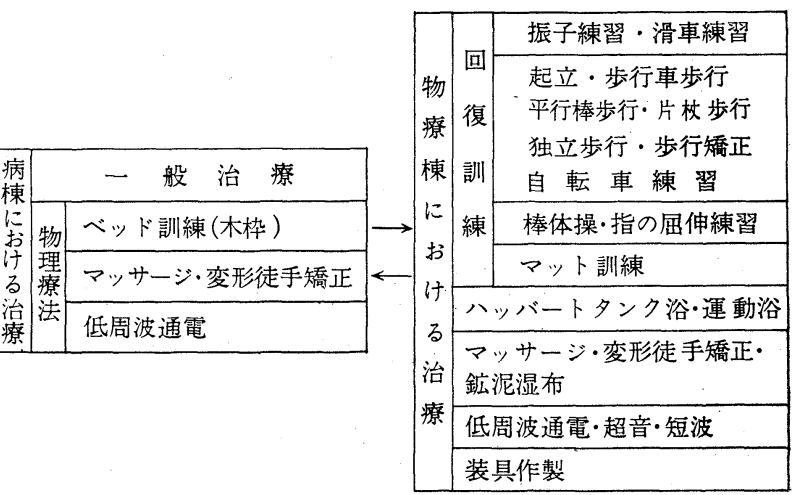

図１リリハビリテーションの概要模型図

一般療法と物理療法に大別されよう。

一般療法は基礎疾患に対する治療であるからこ こで述べるまでもない。

物理療法では自動運動を基調とした回復訓練を 主体とし5)，特に歩行訓練を重視した。従来から 行なわれてきたマッサージ，低周波通電を含めた 電気治療を軽視したのではないが，これらをあく までも補助療法と考えた。水治療法も自動運動の ために利用した。

起坐をはじめとする体位変換などベットにおけ る歩行訓練を終了してから起立・歩行訓練に移行 するのが自然であろうが，入院期間を短縮させる ためには両者を平行させたほうが有利であること を知ってからは打打む㸚この線汇沿った。

歩行訓練をとくに重視したのは，下肢の訓練が 上肢の訓練よりも容易かつ効果的であり，歩ける ようにさえなれば上肢の訓練は家庭に帰ってから でもできるからである。 


\section{III. 回復状態と技術上の問題点}

上肢の回復状況を図 2 亿示す。動作テストと筋 カテストを総合して便宜上，支障なし，ほとんど 支障なし，粗運動かなり，少し動くのみ，まった く動かぬ，の5段階に区分し，入院時と退院時を 比較した。図中斜線で示す部分はいわば手が日常 使いものにならない程度を意味する。入院時に比 して退院時にはまったく動か奴分の者注皆無と なり，粗運動かなりの区分の者あるいは支障なし の区分の者が増加している。したがって上肢の回

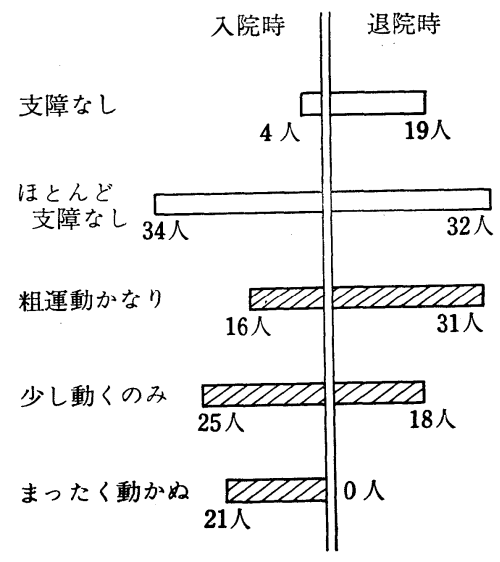

図 2 上肢の回復状況

復はある程度までは期待できるといえるが，斜線 部分の者が多数に残るので，リハビリテーション によって手が使いものになるようになるとはいえ ない。手の運動は足のそれと違ってきわめてデリ ケートであり, 単に腕が動くのみの程度では到底 日常生活に役立たない。

入院中の上肢の回復状態は前述のごとくである が，麻痺は退院後も徐々にではあるが，回復する 傾向があり，数年後に驚くばかりに回復を示して いることがしばしばである。

下肢の回復状況を図 3 亿示す。上肢とほぼ同様 に，支障なし，ほとんど支障なし，片杖歩行可 能，少し動くのみ，まったく動かぬ，の５段階に 区分し，斜線で示す部分はいわば歩けない状態で ある。下肢つ回復状況は上肢より滛かに良好 で, 退院時には全員が片杖歩行可能以上の回復を 示している。したがって，両側不随や運動を禁忌 とする合併症を伴う者以外はリハビリテーション
によってどのようなひどい麻㾝をもった患者も全 員が歩行可能になりうるものだと断言できそうで ある。

因みに歩行開始までの期間は平均 2.7 月で, 短 い者は 1 月，長い者は13月を要している。もとよ り入院時すでに歩行可能であった46人は除外され ている。とくに長期日を要した者は関節の拘縮・ 変形が強く，この矯正に主たる時日を費した者で あり，入院までの期間が長かった者ほどこの傾向 が強い。

主として足関節，まれに膝関節の変形や尖足・

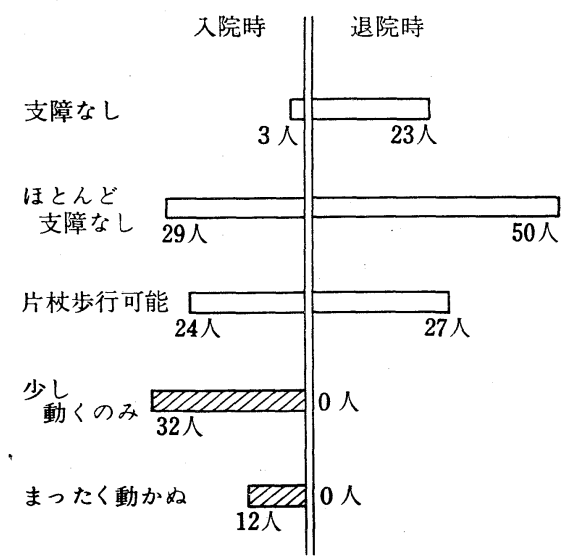

歩行開始までの期間 平均2.7 $(1 \sim 13)$ 月

（ただし入院時すでに歩行可能の46人を除く）

装具を要したもの12人

図 3 下肢の回復状況

内反足のために装具を要した者は 12 人であるが， 装具注簡易なもので，しかも多くは一時的なもの であった。

知覚・言語・知能・感情などの障害もリハビリ テーションにとって重要な因子であるが，これら に対する回復訓練はとくに施さなかったのでその 成績の記載を省略するが，これらの障害も運動機 能の回復とほぼ平行して回復する傾向を示した。

つぎに，治療成績と若干重複するきらいはある が，回復訓練中に共通して生じた技術上の問題点 を拾ってみたい。

1）手の訓練が困難であること。上肢の回復状 況で指摘したが，回復訓練によって足は $100 \%$ 杖 を使えば歩けるまでに回復したが，手は約50\%の 者しか使えるようにならなかった。これは足と手 に要求される運動の精密度の相違に由来した結果 
と思われるが，上肢とくに手の訓練の困難性にも 一因があるように思われる。前腕の水中低周波通 電や斜板上の腕立訓練や指の屈伸練習のための各 種の装置の考案等を試みているが成果を見ない。

2）尖足・内反足に傾きやすく，これが歩行障 害の原因となりやすいこと。各種の筋弛緩剤が出 現し，試みたが期待できなかった。内反足のため に，しばしば足関節を捻挫することがある。足関 節部の装具使用によりすべて解決された。

3）麻痺側の関節にリウマチ様の痛みが起こり やすいこと。四肢の小関節から大関節に至るま で, 各種の形や強さで多くの例にリウマチ様の関 節障害が見られた。発作後 1 月位から起こりはじ め, 関節の軍動が止まっているとしだいに増強 し，ついには関節強直におよぶ。また過度の運動 によっても起こるように思われる。これの予防の ためには，自・他動運動を適度に絶えず継続する 必要がある。比較的少量の副腎皮質ホルモンは症 状を緩解した。

4）訓練を中止すると拘縮に傾くこと。リウマ チ様の関節痛と密接な関係にある。運動を不断に 継続するよう留意するのみでよいが，退院後とく に注意すべき事項となる。

5）言語・知能・感情の障害が回復訓練を阻害 すること。発語不能・読字不能の患者は稀であっ たが，意志の疎通が行なわれ難く，無理な訓練を 強いることもありえよう。高度の言語障害をもっ た患者の 5ち 2 人が心筋硬塞で死亡した。

感情の障害は回復に対する意欲を失わせる。 言語療法師や心理学者の必要を痛感した。

6）両側不随は運動失調をともない歩行不能を きたしやすいこと。両側不随は全例が半身不随の 累加であった。軽度の麻痺でもそうであるが，中 等度以上の麻痺では運動失調を伴い，酩酊様歩行 となり，ときには蹃坐さえも不能である。運動失 調は麻摩のためのみとは到底考えられず，小脳性 性格のものにかなり近いが，今後検討されねばな らない。高度のものは回復訓練の対象となり難 い。

\section{IV，危険 性}

入院中の死亡は 2 人で，いずれも心笳硬塞によ
るものであった。退院後の死亡は 9 人で， 1 人は 胃癌, 1 人は弁膜症, 他の 7 人は脳卒中の再発作 によると考えられる。

入院中 4 人に再発作を見たが，いずれも軽症 で，これがためにリハビリテーションを断念して 中途退院した者はなかった。

古くから「中風 3 年」といわれてきたが，脳卒 中後遺症を有する患者の死亡率を知るための適当

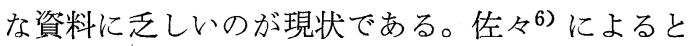
初回発作後 2 年半の死亡率は約 $17 \%$ と考えられ る。

私どもの身近な状況を知るための唯一の資料で ある昭和34年発表の岡山県の調查 (安 江 $\left.^{7}\right)$ に によ ると，脳卒中再発作で死亡した者の約 $80 \%$ が初回 発作後 1 年以内に, 約 $90 \%$ が 3 年以内に死亡して いる。この数字は脳卒中後遺症をもった者が 1 年 以内に $80 \% ， 3$ 年以内に $90 \%$ 死亡したことを意味 寸るものではない。したがって後者の意味におけ る死亡率を知るよしもないが，私共が 7 年閒に扱 った患者 100 人の中 7 人 $(7 \%)$ の再発作死亡率 は佐々（廉）の報告に比べて高いものとは思われ ず，むしろ遙かに低いもののように思われる。

\section{V. 脳卒中後遺症のリハビリテーシ ョンの要否}

最近私どもが岡山県下の60の一般病院院長あて に脳卒中後遺症に対するリハビリテーションの要 否についてアンケートをとらせていただいたとこ ろ, 回答の得られた37病院全部がその必要性あり という結果であった。これはリハビリテーション の必要性が一般にすでに認識されているものと解 してよいであろう。

これまで脳性麻痺が予想外に良い回復を示すこ とは頭部外傷後や脳卒中後に誰しもが経験したこ とであり，その点においては，リハビリテーショ ンの効果は疑問視されていた。私どもの成績から すると，両側不随と運動を禁忌とする合併症を有 する者を除けば，どのようなひどい麻痷・変形が ある者でもほぼ $100 \%$ 歩行可能になると断言でき そうである。この点においてはリハビリテーショ ンの効果に疑問をさしはさむ余地はないであろ う。歩行可能であることは患者自身の喜びである 
ばかりでなく，他人の介助を要する程度をいちじ るしく軽減させる。また歩行運動が生体におよぼ すはかり知れない好影響も当然期待できよう。他 人の介助を軽減し，のみならず適当な労働に従事 できるならば，労働人口の増加を急速に要求しつ つある現下の社会機構の中においてはその意義は とくに大きい。

現在の担当科 $\left\{\begin{array}{lr}\text { 内 科 } & 27 \\ \text { 外科 } & 3 \\ \text { 内科・物療科 } & 2 \\ \text { 整 科 } & 1 \\ \text { 整 科 } & 8 \\ \text { 内科 } & 7 \\ \text { 内科・整科 } & 6 \\ \text { 内科・外科 } & 4 \\ \text { リヘヒリテー } & 4 \\ \text { ション科 } & 4 \\ \text { 内科・物療科 } & 4 \\ \text { その他. } & 3\end{array}\right.$

図 4 岡山県下60一般病院院長に対する脳卒中後 遺症のリハビリテーションの担当科はつい てのアンケートの回答37病院の結果

つぎに，リハビリテーションの効果を認めて も，再発作または循環器系の重篤な合併症を起こ しやすい患者に故意に運動の機会を与えること は，余命を短縮するのではないかとの疑問を持つ 人がある。また，余命の比較的短かい老人に回復 の機会を与えても，その価值は少ないのではない かという疑問も耳にする。これらの疑問はリハビ リテーションに伴う危険性とつながる問題であ る。今後長期にわたる観察が必要であるが，現在 までのところ私どもは危険性が決して高いもので はないと考えている。

回復成績と危険性の両面から脳卒中後遺症のリ ハビリテーションは行なら価值があり，医学的倫 理からすれ行なう必要があるといえる。

\section{VI. 脳卒中後遺症のリハビリテーシ ヨンの担当科}

従来, 脳卒中後遺症の回復は半年ぐらいまでと 一般に考えられてきた。この間は主として内科医 とマッサージ師が治療に当たり，その間に回復し ない者は半ば見捨てられ放置された感がある。基 礎疾患に対する治療のみは続けられたにしても。

麻㾖・拘縮・強直・変形の強い者は基礎疾患は 内科的なものであるにしても，病状はまったく神 経科的なもの，あるいは整形外科的なものであ
る。内科的の問題でありながら，神経科医・整形 外科医の問題でもあるところに盲点が形成されて きたのであろう。表 4 のアンケートの結果からも この間の事情をうかがうことができよう。現在の 病院における担当科もまちまちであるし，将来の 担当科に対する見通しもはっきりしない。しか し，反面このことは何か複数の科で担当す心゙きこ とも暗示している。

私どもの経験からは，理学療法師を十分にかか えたリハビリテーション科（または理学療法科） が絶対に必要であり，患者を基礎疾患に詳しい循 環器専門の内科医が担当し, 整形外科医・神経科 医の協力の下にリハビリテーションを押し進めて いくのが日本の現状ではもっとも望ましいと考え ている。医学的リハビリテーションはこれで良い として, 社会復帰, 職業復帰のためのリハビリテ ーションにはさらに多くの問題を残している。

\section{VII. 患者の経済的負担}

私どもが扱った患者の大部分は経済的に恵まれ た者ばかりであった。歩行不能の患者にはそれぞ れ 1 人の付添いが付き, 患者の経済的負担はかな り大であった。そのうえ，水治療法をはじめとす る特殊治療に要する費用はすべて患者の自己負担 とされた。それゆえ，経済的貧困者は私どもの施 設を利用できなかったものと考える。リハビリテ ーションをあまねく階層に普及させるためには， このような患者の経済的負担を取除かねばなるま い。現在の病院の機構では許されないことかも知 れないが，少なくともこのような患者 4 人に対 し， 1 人の介助人を病院に準備す心゙きであろう。 また，それぞれの特殊治療に相応な保険診療費が 設定されて，患者の自己負担が幾分なりとも軽減 されね洔なるまい。逆に病院は介助人の節減のた めに，患者運搬の労力を軽減できるような病棟と 治療棟との配置関係や運搬器具に対する配慮を要 するであろら。このような見地からは私どもの病 院でさえ不十分な点が多く, 対象患者の莫大さと 照合すれば，脳卒中後遺症のリハビリテーション を専門とする新たな施設の設置が要望される。

おわりに

約 7 年間にリハビリテーションを施した 100 人 
の脑卒中後遺症の自験例を検討した。回復訓練, とくに歩行訓練を中心とした物理療法を行なつ た。全例が片杖歩行可能以上の回復を示したが， 上肢の回復はそれほどでなかった。技術的に，上 肢の訓練の困難性, 言語・知能などの障害, 両側 不随の運動失調の傾向等末解決事項がある。リ八 ビリテーション施行中拉よび施行後の危険性が高 いとは考えられない。脳卒中後遺症のリハビリテ ーションを行ならべきであるという結論に到達し た。循環器病の専門医が患者を担当す心゙きだが， 現状では内科医が担当し, 整形外科医, 神経科医 の協力の下に，理学療法科にリハビリテーション を依頼するのが望ましい。患者の経済的負担を軽 減する必要があり,専門の施設の設置が望ましい。
招わりと御校閲を賜つた院長津田誠次名誉教授, また御指導を賜つた副院長友保誠博士, 整形外科部 長村川浩正博士飞深謝します。御協力を賜つた森一 正主任ほか物療師の諸氏飞謝意を表します。

\section{参考文献}

1) 渡辺定：医学シソポジゥム 21 輯, 21 , 診断と治療 社, 1958. 2) 安江正子：日公衛誌，6,188, 1959 . 3) 佐々木直亮・他：厚生の指標，特集業績発表， 34,1963. 4) 柴田完・他：内科，7，716，1961. 5) Rusk, H.A.:Rehabilitation Medicine, 1958. 6) 佐々(廉)：医学シシポジゥム 21 輯，283, 診断と 治療社, 1959. 7) 安江正子：日公衛誌，6巻， $224 ， 1959$ ．8） 天児民和，中村裕：リハビリテー ション，南江堂，1960. 9) 金久卓也・他：内科, 11，1315，1963. 10）服部一郎：内科，12，719, 1963.

（昭和39年 3 月 24 日受付）
私たちセラピストに課せられた 課題は二つあると思っている。一 つは，その仕事を真の科学として 確立させ発展させていくことだ。 第二は，セラピストの社会的地位 を高めること，平たくいえば，七 ラピストは高給に価する人間なり ，と社会に認めさせることである と思う。この二つは，見る角度に よっては，車の両輪のようなもの であるから，たとえば身分法の制 定などによって，その発展の礎を 作ろうというような時期とは，よ くよく考慮されねばならないこと である。

あえて科学としての確立, とい ったのは，やはりその意味での遅 れが目立つからである。もう二年 ほど前のことになるが，私はある 古い雑誌の中で，興味深い論文を 見つけ出した。これこそ neurophysiological approach という ものを私に教えてくれた最初のも のであるといってよい。その報告

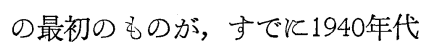
にされていたととは私をくやしが らせた。だがさらに私をくやしが らせたのは，そういう方法のある ことを読んでいた医師があり，そ
してセラピストたちもをれを知らさ れていたにもかかわらず，誰も追試 していなかったことだ。追試の価值 なしの根拠を持ち合わせた上でのこ とではない。先人の残したものに， つぎの世代が積み重ねをていくこと こそ科学の発達というものではある まいか。

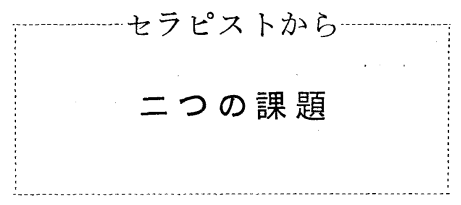

なぜこういうことが起こったのか ?それは，一つマは，今までセラピ イ(ここではP.T., O.T. に限ろう) というものが，医師のリードで行な われてきたことに起因するのではな いだろうか。多くの場合，医師には 医師としての本職があるから,P.T. や O.T.の概論について書物から得 る知識はあっても，それを伝えるば かりで実践することが少ない。医学 は実践的なものであるから, 理論と 臨床経験の間をピストンのように往 復する思考過程が不可欠で，それな くしては進歩は望めないのに, どう も今までの形式はあまり良くなかっ
たようである。加えてセラピスト の方でまた，あまりに受身だった のではあるまいか。何も外国文献 を読さばかりが能ではないが，と れルしても，著名な医師をして，

「日本のセラピストは，自分でど んどん文献を読めないからだめな のです。」などと公式の場でいわせ てしまった責任は，多くのセラピ ストの側とあるといわねばならな い。ともかく,理論は医師の手《 実践はセラピストル，と二分され ることの多かったのは，まさに悲 劇価する。今はもう二分されて いたものを一つの手に交とめるべ き時期である。先日アメリカの友 人から聞いたことだが，彼女の 国では最近 Physical medicine doctor の志願者がめっきり減っ てさた受講者の大部分を占めるの 壮外国という。なぜなら P.T. や O.T. が専門化してきた今日で अ, physical medicine doctor の入り込む余地がなくなってきた からだと。不幸にして日本のリハ ビリテーションはいささか遅れを とったが，乙かし先進国の歴史が 見せてくれる教訓を有効と利用で きる位置にはある。

(Q.P.) 